\title{
National accounting and the valuation of ecosystem assets and their services
}

\section{Carl Obst*}

Melbourne Sustainable Society Institute

University of Melbourne,

Monash Rd, Parkville, 3010, Australia

cobst@unimelb.edu.au

\section{Lars Hein}

Environmental Systems Analysis Group, Wageningen University, PO Box 47, 6700 AA, Wageningen, The Netherlands

\section{Bram Edens **}

National Accounts Department, Statistics Netherlands, The Hague, The Netherlands

* corresponding author

** The views expressed in this paper are those of the author and do not necessarily reflect the policies of Statistics Netherlands

\section{Abstract}

There has long been interest in integrating the value of environmental stocks and flows into standard measures of economic activity and wealth, in particular through the development of adjusted measures of GDP and extended measures of national wealth.

This paper examines how the valuation of ecosystem services and ecosystem assets can be undertaken in an integrated national accounting setting. We clarify the relevant valuation principles, most significantly the need to apply the concept of exchange values, and explain why the integration of ecosystem services necessitates an extension of the standard production boundary used in economic measurement.

The main implications of an accounting approach are discussed including the need to distinguish benefits from services, the need for valuation methods that exclude consumer surplus, and the importance of aligning measures of income and degradation.

Remaining challenges include the treatment of low or negative rents, accounting for ecosystem disservices, and the derivation of values for ecosystem assets. Meeting these challenges and advancing work in this area should be the joint focus of economists, ecologists and accountants. 


\section{Keywords}

Ecosystem accounting, national accounts, ecosystem services, degradation, valuation, green accounting

Abbreviations

CICES common international classification of ecosystem services

EC European Commission

GDP gross domestic product

MA Millennium Ecosystem Assessment

NEA National Ecosystem Assessment

SEEA System of Environmental-Economic Accounting

SEEA EEA System of Environmental-Economic Accounting 2012 Experimental Ecosystem Accounting

SNA System of National Accounts

TEEB The Economics of Ecosystems and Biodiversity

UN United Nations

UK United Kingdom of Great Britain and Northern Ireland

WCED World Commission on Environment and Development

\section{Acknowledgement}

This paper reflects and builds on the outcomes of technical discussions held in the context of the development of the SEEA Experimental Ecosystem Accounting. The three authors were members of the editorial board established by the United Nations Committee of Experts on EnvironmentalEconomic Accounting to oversight that technical work and acknowledge the contributions of other technical experts involved. We also thank two anonymous reviewers for their valuable comments. 


\section{National accounting and the valuation of ecosystem assets and their services}

\section{Introduction}

There is a growing recognition of the importance of ecosystems and biodiversity for sustainable development (UN, 2012) and an increasing interest in assessing the economic consequences of changes to the earth's ecosystems (MA 2005; TEEB 2010; UK NEA 2011). As a result, there are frequent calls to integrate of the value of ecosystem assets and their services into national accounting systems as reflected in the Convention of Biological Diversity Aichi Target 2 (CBD, 2010), in the draft United Nations sustainable development goals (UN, 2014) and in a range of initiatives around natural capital accounting (for example, the World Bank led partnership on Wealth Accounting and the Valuation of Ecosystem Services). These recent developments reflect progress in the development in the field of natural capital accounting over a period of more than 40 years.

The publications by Meadows et. al. (1972) and Ayres and Kneese (1969) pointed towards the importance of the environment for economic development, which according to a literature survey by Pezzey and Toman (2002) "provoked a response" from the economics community that started analyzing these issues by including non-renewable natural resources in macroeconomic models (for example, Dasgupta and Heal, 1974; Solow, 1974; Hartwick, 1977). A seminal contribution was provided by Weitzman (1976). He established (under certain assumptions) a welfare interpretation of GDP as "the stationary equivalent of future consumption" in which national income equals the return to wealth. These articles initiated a "green accounting literature" which analyzes the relation between concepts such as income, wealth, and welfare in theoretical models including the role of natural resources (see Heal and Kriström 2005 for an overview).

The extent to which measures of national income are related to measures of social welfare had previously been discussed by prominent economists, and two main traditions developed (Vanoli, 2005). On the one hand, economists such as Pigou and Hicks sought to relate observed market values to the framework of utility theory but this approach proved difficult, leading Hicks (1975) to conclude that "it is clear we cannot have - an index of welfare". An alternative approach following Kuznets (1954) tried to measure the final objectives of economic activity. This approach naturally led to a desire to adjust measures of aggregate economic activity, commonly GDP, for various elements of 
welfare not captured in those measures, as exemplified by the pioneering work of Nordhaus and Tobin (1972) and their macro-economic welfare index. ${ }^{1}$ The main difficulty with this approach however has been the relative arbitrariness of the adjustments, as demonstrated by the range of alternative indicators that have been proposed subsequently (e.g. the index of sustainable economic welfare, Daly and Cobb 1989; the genuine progress indicator Cobb et. al., 1995).

While the green accounting literature may have offered a promising way forward, many national accountants, responsible for the measurement of gross domestic product (GDP), concluded that it was not a helpful approach since it was situated "at a very high level of abstraction without searching any longer for any relationship to actual national accounting measurements" (Vanoli, 2005). Instead a more empirical approach was followed in the official statistical community, where the first steps to integrate environmental and natural resource information into the national accounts took place in the 1970s and 1980s with early work in Norway (Alfsen et. al., 1987), France (Commission interministérielle du patrimoine naturel, 1986) and the Netherlands (Hueting, 1980).

These developments progressed steadily (for a summary see Ahmad et. al., 1989) and in the early 1990s the international official statistics community through the United Nations Statistical Commission released the 1993 Handbook of National Accounting: Integrated Environmental and Economic Accounting (UN, 1993). This release reflected calls from the first UN Conference on Environment and Development for the development of extended national accounts (UN, 1992) following on from the highly influential report of the World Commission on the Environment and Development (WCED, 1987).

Ongoing research and discussion within the statistical community culminated in the adoption in 2012 by the United Nations Statistical Commission (UNSC) of the System of Environmental-Economic Accounting (SEEA) 2012 Central Framework (UN et. al., 2014) as an international statistical standard. (A summary of these developments is provided in UN et. al., 2014. ${ }^{2}$ ) Further, in 2013 the UNSC endorsed the development and testing of a body of work referred to as ecosystem accounting as synthesized in SEEA 2012 Experimental Ecosystem Accounting (SEEA EEA) (UN et. al., 2013). It is the work on ecosystem accounting that has raised again the issues of valuation for non-market environmental assets and services and hence forms the point of departure for this article. 
While the release of the SEEA documents is an important milestone for the national accounting approach, there remain a number of challenges in integrating measures of ecosystem assets and services into the standard national accounts (see for example, Mäler et. al., 2009; Campos and Caparrós, 2011; Banzhaf and Boyd, 2012; Edens and Hein, 2013). The particular challenge that is the focus of this paper is valuation.

What has re-emerged through the development of SEEA EEA is that the concepts of value and approaches to the valuation of environmental stocks and flows that are appropriate for national accounting purposes are different from those applied by economists in other situations. In particular, there are some differences in concept compared with the welfare theoretic approach to valuation either in the measurement of wealth (Dasgupta, 2009; Arrow et. al., 2003, 2012; World Bank, 2011; Barbier, 2013); or where the purpose of valuation is assessment of the changing surpluses of specific economic agents (e.g. Bateman et. al., 2013). The treatment of consumer surplus is a particular issue in this latter situation since consumer surplus is excluded from national accounts valuation. These differences have, at times, evoked criticism of environmental-economic accounting by the environmental economics community (e.g. Heal and Kristöm 2005).

The objective of this paper is to examine how the valuation of ecosystem services and ecosystem assets can be undertaken in a manner that best supports integration with the standard national accounts. It is not suggested that these valuations should replace valuations developed for other purposes. An analogy can be made to the measurement of the costs and benefits of public health. The accepted valuation of public health for national accounts purposes is based on the costs of delivering the health services. Valuation of the outcomes from investment in public health will take into account a much wider set of considerations. Neither valuation is necessarily right or wrong, but both are likely fit for purpose. Explaining the nature and relevance of alternative valuation concepts for different purposes is at the heart of this paper.

In Section 2, the key elements of the national accounting approach to valuation are described including discussion of the link to shadow prices and the types of non-market valuation methods that may be used for national accounting purposes. In Section 3, we summarise recent work to extend the standard national accounts to the measurement of ecosystems. Section 4 discusses the implications of taking a national accounting perspective in the valuation of ecosystem assets and ecosystem services. Section 5 describes some of the remaining challenges for ecosystem accounting, and in Section 6, we conclude, 
highlighting the need for ongoing engagement and discussion between the national accounting, ecological and economics professions.

\section{Valuation for national accounting purposes}

The valuation of ecosystem services and ecosystem assets is required for full integration of these stocks and flows into the standard national accounts (e.g. via adjusted measures of national income, saving and wealth). This section outlines the valuation concepts applied in the national accounts, describes how they relate to other valuation concepts that are used and discusses the rationale for the use of national accounts based valuations.

Income as an aggregate measure of economic activity, not welfare

It is important to recognize that the System of National Accounts (SNA) does not consider its measures of income as measures of welfare. The 1993 SNA states a "link [exists] between changes in aggregate production and consumption and changes in welfare. However, changes in the volume of consumption, for example are not the same as changes in welfare" (UN et. al., 1993, para 1.76.). The 2008 SNA is more explicit in warning against a welfare interpretation of GDP: "GDP is often taken as a measure of welfare, but the SNA makes no claim that this is so and indeed there are several conventions in the SNA that argue against the welfare interpretation of the accounts.” (EC et. al., 2009, para 1.75). Rather the main objective of the SNA is to "compile measures of economic activity in accordance with strict accounting conventions based on economic principles." (ibid para 1.1). Although the SNA has stated its position clearly, the question of exactly how aggregate measures of national income should be interpreted in a welfare context remains (see Hill and Hill, 2003) and is significant in understanding the nature of adjustments to income for the cost of using capital (e.g. adjustments for degradation) and the treatment of revaluations of assets. This issue is explored further in section 4. 
The core national accounts valuation concept is the application of market prices noting that this term is defined very specifically for national accounting purposes. From a strict national accounting perspective, "market prices are the amounts of money that willing purchasers pay to acquire goods, services or assets from willing sellers" (EC et al. 2009, para 3.119). The 2008 SNA goes on to observe that "a market price refers only to the price for one specific exchange under the stated conditions. A second exchange of an identical unit, even under circumstances that are almost exactly the same, could result in a different market price" (EC et al. 2009, para 3.119). To distinguish the national accounts concept from other interpretations of the term "market prices", the remainder of this paper refers to the national accounts value concept as reflecting "exchange values", i.e. the value at which goods, services and assets are exchanged regardless of the prevailing market conditions.

The application of the exchange value concept applies not only to transactions between economic units but also to the valuation of assets. In the compilation of balance sheets and estimation of wealth, the relevant valuation for an asset is the price for which it would have been exchanged if a transaction had taken place on the balance sheet date (EC et al. 2009, para 13.18). Since many assets are not actively traded various approaches are applied to estimate asset values including (i) the values of similarly traded items (e.g. in the valuation of the housing stock); (ii) the written down replacement costs i.e. deducting the accumulated depreciation (most commonly used for valuing produced assets); and (iii) the discounted value of future returns or net present value. The use of net present value techniques is most commonly adopted in the valuation of natural resources although there are in fact only a few countries that regularly estimate these values (see World Bank 2011, Chapter 8 for a recent overview).

Exchange values are quite distinct in concept from the shadow prices used in wealth accounting. These prices reflect the marginal contributions of assets to well-being (Dasgupta, 2009) and incorporate the effects of relevant externalities and use underlying assumptions regarding social welfare functions and future economic states (PIB, 2013). Using this approach to valuation leads to a measure of wealth that is the sum of all assets measured at their shadow prices (Arrow et al., 2012, Dasgupta, 2009, UNUIHDP, 2014). 
The rationale for exchange values in national accounting

The differences between exchanges values and shadow prices reflect two fundamental aspects of measurement in national accounting. First, as noted in the SNA, an exchange value "should not necessarily be construed as equivalent to a free market price; that is, a market transaction should not be interpreted as occurring exclusively in a purely competitive market situation. In fact a market transaction could take place in a monopolistic, monopsonistic, or any other market structure." (EC et al. 2009, para 3.119).

Second, this implies that externalities are, in principle, not accounted for as they are defined in terms of welfare rather than in terms of exchange. The 2008 SNA also observes that, since externalities are not market transactions, values of them will not reflect an equilibrium situation, and the economic behavior of the units may change considerably if actual payments were introduced (EC et al. 2009, para 3.93).

Since there is a long history of economic theory and practice underpinning the logic of, shadow prices, welfare effects, consumer surplus, incomes and wealth, the rationale for the use of exchange values for accounting is the subject of criticism (e.g. Heal and Kriström, 2005).

Aside from the practical observation that exchange values are far easier to observe and estimate than shadow prices, there is one main response to this criticism. It is that the use of exchange values ensures the integrity and consistency of the accounts since the use of exchange values implies an equivalence in the recording of the amount of money paid by the purchaser and the amount of money received by the seller. If amounts that the purchaser or seller may have been willing to pay or accept were used instead (i.e. the shadow prices of each transactor), then the accounts of the different economic actors would not be balanced and the actual flows of money involved could not be reconciled. Only the use of the exchange value concept across all transactions and assets can ensure that the different measures of GDP balance and that the recorded measures of income and wealth for different sectors align.

In wealth accounting this issue does not arise since the objective is to consider one country or one actor at one time rather than balancing valuations between multiple countries or multiple economic actors. Thus, while the use of shadow prices are well suited for wealth accounting purposes they are not well suited to national accounting purposes, for example for making adjustments to current measures of GDP. 
If the purpose is to integrate values of ecosystem stocks and flows within the standard national accounts and hence obtain adjusted measures of income and wealth, then the challenge that faces the national and environmental accountant is how the concept of exchange values can be applied in the area of ecosystems and particularly how the broad range of non-market services can be accounted for. Clearly, the valuation approach applied in accounting has repercussions for the interpretation of the values presented in accounting, as further discussed in Section 4 (see also Bateman et al. (2011) for a review of valuation approaches and the respective implications of using these approaches).

\section{The national accounts boundary for valuation}

Central to the question of the integration of ecosystem information into standard measures of income and wealth is the current measurement boundary for aggregates such as GDP. GDP is defined by a production boundary, where production is defined initially in general terms as incorporating "activity carried out under the control and responsibility of an institutional unit that uses labour, capital and goods and services to produce outputs of goods or services" (EC et al. 2009, para 6.24).

From this starting point a number of clarifications and conventions are applied to determine the standard SNA production boundary. The key point relating to the measurement of ecosystems is that a purely natural process without any human involvement or direction is not production in an economic sense (EC et al. 2009, para 6.24) $)^{3}$. Here the distinction is made between (i) the active cultivation of crops, livestock, orchards and other biological resources which is included in the production boundary, and (ii) the growth of natural resources (such as timber in primary forests, fish on the high seas) which is not under the control of an economic unit and hence lies outside the production boundary. While the growth of natural resources is not considered production, the harvesting of those natural resources is within the production boundary (e.g. through logging or fishing activity).

Overall, in this framing, ecosystem services, defined in the SEEA EEA as the contribution of ecosystems to economic and other human activity (UN et. al., 2013), lie outside of the production boundary since they reflect ecosystem processes rather than human or economic processes. The integration of ecosystem services into the national accounts framework thus requires a re-consideration of the standard production boundary. This re-consideration is described in Section 3. 
In addition to reconsidering the production boundary, there is a need to consider the application of exchange values in non-market situations. A key question when accounting for ecosystem services is how the concept of exchange value can be applied when non-monetary transactions are involved (Campos and Caparrós 2011; Edens and Hein 2013). While, the national accounts are often understood to provide a measure of the market economy, in fact, the national accounts measures of income and production include a wide range of non-market and quasi-market situations such as the activity associated with government provision of education, health and defence and subsistence agriculture, forestry and fishing activity. To ensure measurement coherence in the aggregation of market and nonmarket activity, i.e. the consistent application of exchange values, national accountants have articulated specific concepts and treatments concerning valuation.

When monetary transactions are not in evidence there are two principal approaches that are used to estimate the relevant exchange value of transactions between economic units. The first best alternative is to use the exchange value of the same or a similar item. This approach is most suitable if the item is traded in sufficient numbers and in similar circumstances. It is most commonly applied in the measurement of barter and subsistence agriculture and the estimation of imputed rent. In such situations there are generally functioning markets providing observable prices for the same or similar products. $^{4}$

The second best approach is to estimate the exchange value based on the costs of production which is most commonly applied in the measurement of public services such as health, education and national defence. For example, following this approach, the value of the output of health services is estimated as the sum of intermediate consumption of goods and services, labor costs, and the consumption of fixed capital (i.e. depreciation) in the health sector.

Overall, while the SNA recommends that non-market activity should, in principle, be valued at cost, this does not equate to the conclusion that all non-monetary transactions should be valued at cost, as shown in the case of barter or the imputed rent on owner-occupied dwellings. 
Discussion on how these non-market, exchange valuation principles can be applied to national accounting for ecosystems is ongoing. A range of approaches exists for valuing natural resources and ecosystem services (e.g. Brander et. al., 2005; Brouwer et. al., 2009; Bateman et. al., 2011). Approaches that seem most appropriate for the estimation of exchange values (see also UN et. al., 2013 chapter 5) include:

Resource rent (called residual imputation or net rents by Brouwer et. al., 2009). The resource rent method derives the value of the ecosystem service as a residual after the contributions of other forms of capital have been deducted from the operating surplus. Since the residual reflects the return to the ecosystem asset that is used in production of marketed goods, it is consistent with exchange values.

Production / cost functions These approaches relate the output of marketed goods (timber, fish, etc.) to the inputs of ecosystem services through the use of econometric techniques. Since the point of departure is exchange values for marketed goods, the resulting values for ecosystem services will be consistent with values already used for national accounting.

Marginal values from revealed demand functions A range of techniques that are commonly used to assess changes in welfare require the derivation of demand functions. Based on derived demand functions it is possible to envisage the estimation of a marginal exchange value by choosing a point along the demand function: this point could be either chosen based on observed behavior (e.g. the actual number of visits to a wild park without access fees); or through intersection with a modeled supply curve (see Campos and Caparrós (2011) who refer to this as a simulated exchange method).

Replacement cost approaches. Particularly for the valuation of services from certain ecosystem processes (e.g. air filtration, water purification), replacement cost approaches may be useful for national accounting purposes although there are many concerns about this approach from a welfare measurement perspective (see for example Barbier, 2014). These approaches consist in estimating the value of flows based on the additional costs of the next best alternative for replacing the ecosystem service in question. Necessary conditions for their application are that valuation is based on the least-cost alternative and that replacement of the service is to be expected in case it would be lost (National Research Council, 2005). It is 
noted that there may be a role for stated preference based approaches in determining whether replacement would indeed take place The replacement cost approach is aligned with SNA conventions as it combines two elements inherent in the SNA approach to valuation: valuation based on similar items and valuation at cost for non-market services.

Hedonic pricing approaches. These approaches involve decomposing the values of marketed assets (e.g. houses) into prices for the component or characteristic elements. Differences in values may then be attributed to specific characteristics including ecosystem services. Since the values of the assets are at exchange values the resulting decomposition would reveal prices for ecosystem services that are appropriate for national accounting purposes.

Approaches that are not appropriate for estimating exchange value are those methods that generally include consumer surplus such as stated preference methods and some applications of the travel cost method. Also not appropriate for accounting purposes is the use of estimated environmental or ecosystem restoration costs as discussed further in section 4.

In practice of course there are many measurement challenges that arise in estimating exchange values for ecosystem services and ecosystem assets. Some key challenges are discussed in Section 5. 


\section{The accounting model of SEEA Experimental Ecosystem Accounting}

As noted in the introduction, there has been a long history of work to integrate environmental stocks and flows into the national accounts (e.g. Harrison, 1993; Vanoli, 1995) but no definitive treatment has been reached. The most recent addition to the national accounting literature on this topic is the SEEA 2012 Experimental Ecosystem Accounting (SEEA EEA) (UN et. al., 2013). This section describes the ecosystem accounting approach to form a basis for the discussion of how the values of ecosystem services and ecosystem assets may be integrated into the standard national accounts.

Ecosystem accounting is a comprehensive approach aimed at incorporating physical and monetary expressions of ecosystem services and the associated ecosystem assets within an accounting framework that is based on the accounting concepts used in the SNA. The ecosystem accounting approach brings together the advancing research on ecosystem services (e.g. MA 2005; TEEB 2010; UK NEA 2011), research on the measurement of biodiversity and ecosystem functioning (e.g. Hooper et al. 2005; Folke et al. 2004), and aspects of environmental-economic accounting around the treatment of ecosystems and the non-resource functions of the environment.

The value added of the ecosystem accounting approach is its synthesis of these different strands of thinking such that the conceptualization and measurement of ecosystem services, and their monetary values, can be considered in a national accounting context. Compared to the SEEA 2012 Central Framework, ecosystem accounting presents a broader and holistic perspective on ecosystems and pays specific attention to the spatial diversity of ecosystems and the services they generate (UN et al. 2013; Edens and Hein, 2013, Remme et al. 2014). Further, SEEA EEA extends the measurement scope of production and assets compared to the SEEA 2012 Central Framework and the SNA, and in this regard represents a considerable development in national accounting. ${ }^{5}$

The ecosystem accounting conceptual model is depicted in Figure 1. It is an adaptation for accounting purposes of ecosystem service models presented in MA (2003), TEEB (2010) and Haines-Young and Potschin (2013). In the model, ecosystems are delineated spatially with each spatial area representing an ecosystem asset. Since the intent is to account for ecosystems and their services at national level (or at least for multiple ecosystems) the spatial areas must be mutually exclusive to avoid double counting. 
Spatial analysis facilitates the modeling required to link ecosystem services to economic units given the spatial diversity of ecosystems and the multiple scales at which ecological processes operate. ${ }^{6}$

Figure 1: Stylised model of stocks and flows for ecosystem assets and ecosystem services

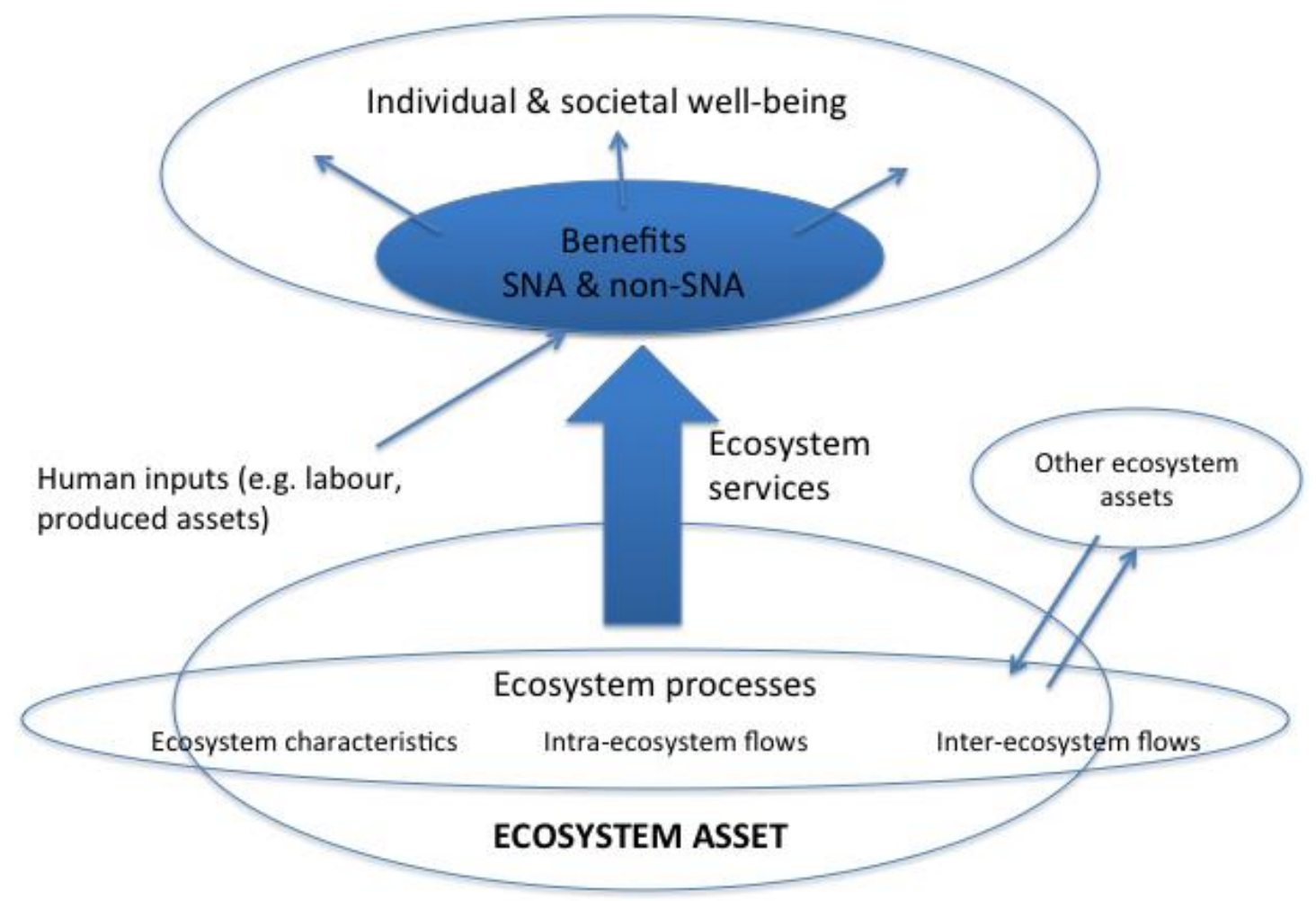

Source: UN et al. 2013, Figure 2.2, p 22

Each ecosystem asset has a range of ecosystem characteristics - such as land cover, species diversity, soil type, altitude and slope, climate, etc. - and reflects a range of ecosystem processes - such as water flows, primary productivity, etc. Measures of the various characteristics and processes together describe the condition and functioning of the ecosystem asset. Note that in Figure 1 only a single asset (spatial area) is shown whereas in reality multiple assets (adjoining areas) will need to be accounted for and ecosystem processes will commonly cross the boundaries for individual assets (e.g. water flows from upstream forests to downstream wetlands).

Important aspects of the accounting approach described in SEEA EEA are assessing the condition of each ecosystem asset on a regular basis over time, and accounting for the changes in condition of each ecosystem asset, including ecosystem degradation. 
Through the functioning of each ecosystem asset there will be "flows reflecting that people, through economic and other human activity, take advantage of the multitude of resources and processes that are generated by ecosystem assets" (UN et al. 2013, p19). It is these flows that are considered to be ecosystem services. Ecosystem services are considered contributions of ecosystems to benefits where benefits in this model do not equate to welfare or well-being but rather correspond to the concept of "products" in national accounting. The term "benefits" was chosen in the SEEA EEA to recognize that the scope is broader than products as applied in the SNA and also to recognize the distinction between benefits and ecosystem services. ${ }^{7}$

Consistent with a number of approaches to the measurement and valuation of ecosystem services, (for example, Boyd and Banzhaf 2012; Barbier 2013; Edens and Hein 2013) SEEA EEA focuses on accounting for "final" ecosystem services, i.e. those flows where there is an immediate connection between the ecosystem asset and a beneficiary in the form of an enterprise, government unit, household, individual or society. For example, the provision of timber from forests is considered a final ecosystem service whereas the associated soil formation and nutrient cycling in forests are considered supporting or intermediate services. Final ecosystem services are grouped into three broad categories following the Common International Classification of Ecosystem Services (CICES) (Haines-Young and Potschin 2013), namely provisioning services characterized by the extraction of food, fibre and materials from the environment; regulating services such as air filtration, carbon sequestration and water purification; and cultural services such as the provision of recreational opportunities, or spiritual and cultural experiences.

Generally speaking, all provisioning and cultural services are considered final services but the treatment of regulating services is more complex since these services reflect the interaction of the economy and humans with ongoing ecosystem processes such as flood protection, air filtration and water purification which are not solely of benefit to humans. Further, regulating services may provide benefits to individuals (as in air filtration leading to better air quality and reduced incidence of pollution related diseases); or by facilitating economic activities (e.g. where water retention by native vegetation reduces flood risks for farming land used for crop production) (see UK NEA 2011). Hence the category regulating services includes both final and intermediate services.

From the perspective of valuation, the focus on final services enables identification of ecosystem services that are inputs to the production of benefits, as distinct from flows associated with the ongoing 
operation and functioning of an ecosystem, i.e. intermediate or supporting services. The creation of a "chain" of flows linking well-being, benefits, ecosystem services, human inputs (produced assets, labour, etc.) and ecosystem processes is central to determining the relevant exchanges and transactions that underpin accounting approaches to valuation.

\section{Implications for valuation from an ecosystem accounting perspective}

The single most important development in the ecosystem accounting model is the expansion of the production boundary to include a full suite of ecosystem services. This expansion underpins, using standard national accounting principles and conventions, expanded measures of income and consumption and facilitates the attribution of ecosystem degradation to expanded measures of income. These fundamental developments and related implications are explored in this section.

Ecosystem accounting requires a distinction between ecosystem services and benefits

As shown in the basic ecosystem accounting model (Section 3), distinctions are made between ecosystem services, the benefits (i.e. the goods and services) to whose production the ecosystem services contribute, and well-being that arises from the consumption of benefits. The valuation focus in ecosystem accounting is on final ecosystem services including those that contribute to benefits within the current scope of GDP and benefits outside that scope - i.e. non-SNA benefits. This approach is consistent with studies such as TEEB (2010) and Boyd and Banzhaf (2009) but it is not aligned with other studies such as the MA (2005) and valuation work by, for example, Costanza et al. (1997, 2014) where ecosystem services are equated to benefits.

For most provisioning services and for a range of cultural services, the benefits to which ecosystem services contribute are within the production boundary of the SNA and hence have prices and values that are included in GDP. In these cases the accounting logic reinforces that ecosystem services are distinct flows (outputs of ecosystem assets) and reflects that the production boundary has been 
expanded to capture the full value of the ecosystem services. These additional outputs are integrated by extending the traditional scope of supply and use of products to establish a longer chain of flows from economic and human activity to the ecosystem.

The chain of flows is central to resolving issues of double counting within the accounting framework since it allows inputs and outputs to be clearly recorded and appropriately netted out to avoid double counting in the derivation of aggregates such as value added and GDP (see also Edens and Hein 2013). Thus, for example, ecosystem services such as grass produced for livestock grazing are also recorded as additional inputs to the production of livestock and hence overall value added (GDP) is unchanged.

In cases where final ecosystem services feed into benefits that are not recorded in the standard national accounts a similar accounting logic applies but the impact on GDP is different. In this case the consumption of ecosystem services that occurs when the services are used reflects the generation of additional goods and services. These new goods and services (non-SNA benefits) are treated as the final consumption of households and government (on behalf of society) or as exports. It is these additions to final demand, such as the additional consumption related to air filtration services, that represent an increase in GDP arising from the final ecosystem services, conditional on these ecosystem services representing additional services rather than contributing to the production of currently measured goods and services.

These accounting steps are shown in Figure 2. Figure 2 is a stylized supply and use table and is divided into three parts. Part A reflects a standard recording, i.e. no ecosystem services, of timber production for furniture purchased by households. The recording ignores all other inputs and potentially relevant flows (e.g. labour costs, retail margins).

Part B extends this recording to include the flow of the provisioning service of timber from the ecosystem asset (the forest) to the forestry industry. The main effect is to partition the value added of the forestry industry between the industry and the ecosystem asset. Note that the overall value added is unchanged (at 80 currency units) even though total supply has increased. This reflects the increase in the production boundary and demonstrates how the accounting framework deals with the challenge of double counting.

Part C introduces a second ecosystem service, air filtration, which is generated by the ecosystem asset. Again total production is increased but in this case value added also rises since the additional 
production is not an input to existing products. The increase in value added is also reflected in increased final demand of households.

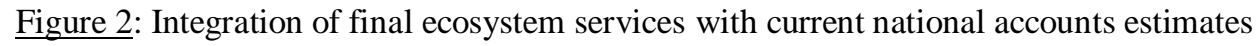

\begin{tabular}{|c|c|c|c|c|c|}
\hline & $\begin{array}{l}\text { Ecosystem } \\
\text { asset (Forest) }\end{array}$ & $\begin{array}{l}\text { Forestry } \\
\text { industry }\end{array}$ & $\begin{array}{l}\text { Manufacturing } \\
\text { industry }\end{array}$ & $\begin{array}{l}\text { Households } \\
\text { Final } \\
\text { Demand }\end{array}$ & TOTAL \\
\hline \multicolumn{6}{|l|}{ PART A } \\
\hline \multicolumn{6}{|l|}{ Supply } \\
\hline Logged timber & & 50 & & & 50 \\
\hline Furniture & & & 80 & & 80 \\
\hline \multicolumn{6}{|l|}{ Use } \\
\hline Logged timber & & & 50 & & 50 \\
\hline Furniture & & & & 80 & 80 \\
\hline Value added (supply less use) & & 50 & 30 & & 80 \\
\hline \multicolumn{6}{|l|}{ PART B } \\
\hline \multicolumn{6}{|l|}{ Supply } \\
\hline $\begin{array}{l}\text { Ecosystem service - growth } \\
\text { in timber }\end{array}$ & 30 & & & & 30 \\
\hline Logged timber & & 50 & & & 50 \\
\hline Furniture & & & 80 & & 80 \\
\hline \multicolumn{6}{|l|}{ Use } \\
\hline $\begin{array}{l}\text { Ecosystem service - growth } \\
\text { in timber }\end{array}$ & & 30 & & & 30 \\
\hline Logged timber & & & 50 & & 50 \\
\hline Furniture & & & & 80 & 80 \\
\hline Value added (supply less use) & 30 & 20 & 30 & & 80 \\
\hline \multirow{2}{*}{\multicolumn{6}{|c|}{ PART C }} \\
\hline & & & & & \\
\hline \multicolumn{6}{|l|}{ Supply } \\
\hline $\begin{array}{l}\text { Ecosystem service - growth } \\
\text { in timber }\end{array}$ & 30 & & & & 30 \\
\hline $\begin{array}{l}\text { Ecosystem service - air } \\
\text { filtration }\end{array}$ & 15 & & & & 15 \\
\hline Logged timber & & 50 & & & 50 \\
\hline Furniture & & & 80 & & 80 \\
\hline \multicolumn{6}{|l|}{ Use } \\
\hline $\begin{array}{l}\text { Ecosystem service - growth } \\
\text { in timber }\end{array}$ & & 30 & & & 30 \\
\hline $\begin{array}{l}\text { Ecosystem service - air } \\
\text { filtration }\end{array}$ & & & & 15 & 15 \\
\hline Logged timber & & & 50 & & 50 \\
\hline Furniture & & & & 80 & 80 \\
\hline Value added & 45 & 20 & 30 & & 95 \\
\hline
\end{tabular}


The distinction made in ecosystem accounting between ecosystem services and the ecosystem assets that generate them, extends to the measurement and valuation of ecosystem degradation. A decline from one year to the next in the aggregate supply of a basket of ecosystem services does not necessarily imply degradation. The aggregate supply may fall due to changes in the demand for ecosystem services rather than due to falling condition; or may fall because the management of an ecosystem imposes limited or no access to resources to encourage recovery of the stock (e.g. in the case of over-fished marine areas). Hence, analogously to the definition of depreciation of produced assets in standard national accounts, degradation reflects the decline in the capacity of the ecosystem asset to provide services due to changes to its condition (UN et. al., 2013). Thus degradation is most associated with the measurement of ecosystem assets. Assessment of the monetary value of degradation requires an understanding of trends in the expected value of flows of ecosystem services in future accounting periods. These trends will be dependent on the condition of the ecosystem assets and hence its capacity to generate future flows of ecosystem services. Note that there may be ecological variations, e.g. in rainfall, that do not necessarily imply a long term trend in the ecosystem's capacity to generate services, and that changes in capacity need to be analysed over an extended period of time Hence, the measurement of degradation must bring together an understanding of changes in ecosystem condition and an understanding of the capacity for an ecosystem to generate specific ecosystem services. As challenging as this seems, the same task is required of accountants in measuring depreciation of produced assets where an understanding of depreciation profiles and changes in the productive capacity of assets must be considered in assessing how the value of an asset changes over time.

As outlined in SEEA EEA Chapter 6, the valuation of ecosystem degradation requires understanding changes in the value of the ecosystem asset. At any point in time, from a national accounting perspective, the value of an ecosystem asset is the sum of the net present values of each ecosystem service generated by the asset under current management. Consequently, ecosystem degradation is not a variable that can be estimated directly but rather requires the application of a sequenced approached with the valuation of individual ecosystem services being just one step in the sequence. 
The measurement of degradation is one of the most analytically meaningful within the accounting system. As is the case in standard economic accounting, a variety of assumptions must be made about the relationship between income (for ecosystem accounting the income refers to the ecosystem services) and capital (i.e. the ecosystem assets). However, it is only by working through these steps that a measure of degradation can be derived which legitimately, can be integrated with standard measures of depreciation and used to adjust aggregate income measures such as GDP.

Aligning measures of income, ecosystem degradation and the treatment of revaluation

The definition of income and the links to changes in wealth have been long-standing questions for economists and accountants alike (Hicks 1946; Weitzman 1976; Hill and Hill 2003; Dasgupta 2009). The national accounts concept of income is, according to Hill and Hill (2003), close to what they define as ex post generalized Hicksian income. That is, it compares wealth at the beginning and end of the accounting period from an ex post perspective and thus in the case of unexpected changes in wealth (for example, due to discovery or catastrophic loss) not all of the change is included in the measure of income. For unexpected changes to be consistently included as income, the production boundary would also need to be adjusted such that the unexpected events would then be considered as part of regular economic activity.

Consistently, for the national accounts, measures of depreciation, depletion and degradation, which are all considered deductions from income, only relate to the loss of capital due to economic activity, i.e. production, and thus the scope of income and degradation are aligned. Loss of capital for other reasons, including catastrophic losses and revaluations due solely to price change, are accounted for in other parts of the national accounting system (specifically the other changes in asset account) such that the change in wealth is fully reconciled.

An alternative concept of income is the Haigs-Simon's income measure that compares the ex post wealth at the end of the accounting period with the ex ante wealth at the beginning of the period (Hill and Hill, 2003). According to this income measure, unexpected changes in wealth (e.g. through discoveries or a lottery win) are included as income in full since they could be entirely consumed and still allow an individual to remain as well off at the end of the accounting period. It is this income 
concept that seems closest to what is found in the wealth accounting literature which includes all types of "net investment" in current measures of income (Dasgupta, 2009; Barbier, 2013) since most of these theories are formulated in a deterministic setting.

Given the use of a different concept of income in wealth accounting compared to the national accounts, then it is inappropriate to use measures of degradation and revaluation of assets derived from wealth accounting approaches to adjust measures of GDP or national income as measured in the national accounts. Consequently, adjusted income approaches, such as those outlined in Barbier (2013), should consider further the alignment of income concepts that are involved and the nature of the proposed adjustments for revaluation and ecosystem degradation.

Restoration cost approaches are not appropriate for valuing ecosystem degradation for national accounting purposes

Given the challenges of valuing ecosystem assets and hence compiling estimates of ecosystem degradation, a commonly considered approach to placing a value on degradation is estimating the costs that would need to be incurred to restore the ecosystem asset to its condition at the beginning of the accounting period (Harrison 1993; UN 1993; Weber 2012). These costs have been labeled 'restoration costs' - noting that they differ from the concept of replacement costs that are used to estimate the value of an single ecosystem service on the basis of the costs of man-made alternatives for that service (National Research Council, 2005). However, from an accounting perspective restoration costs should not be considered an estimate of the value of degradation.

The use of restoration costs to value degradation does not provide an accounting equivalent to the measurement of the depreciation of produced assets. The objective in measuring depreciation is to assess how much the future income earning potential of a businesses' produced assets has been lost through the use of the assets in production (EC et al. 2009). To make this assessment the underlying assumption is that the value of the produced assets reflects the future income and hence changes in the value of the asset will relate to the amount of depreciation. In the measurement of depreciation specified in the SNA there is no requirement that the produced assets in question be "restored" to their original condition - it is not a "new for old" calculation. Rather, measures of depreciation show how 
much it would cost to replace the produced asset (embodying the services it provides) at the end of the period, in its condition at the end of the period. Note that here, the term "replace" rather than "restore" is used deliberately to indicate that there is no intention of changing the condition of the asset in question.

The parallel accounting logic of replacement in the condition at the end of the period must apply in the case of estimating ecosystem degradation. That is, the effort must be made at each point in time to determine the value of the ecosystem asset, i.e. the value of each of the different services expected to be generated by the asset, based on its actual condition at that point in time. The step of restoring an asset (equivalent to the act of investment in produced assets) is a separate decision and a separate accounting entry. Clearly, undertaking work to restore an ecosystem during an accounting period should improve the condition of the ecosystem at the end of the period. However, for ecosystems, there is no market mechanism that might enforce the notion that the amount spent on restoration is directly related to the future income (i.e. value of the basket of ecosystem services) from that ecosystem.

Note that the logic of using restoration cost has been influenced by the accounting work of Vanoli (1995) in which he commences by considering the value of environmental services that arise in the case of an environment degraded by pollution. His proposal is to value the services at the cost of restoring the degraded environment. There are two reflections that arise from the more recent discussion around ecosystem services and accounting.

First, Vanoli's objective of valuing environmental services using restoration costs is in fact, more akin to the replacement cost approaches for valuing individual ecosystem services rather than reflecting the value of ecosystem degradation itself. The problem however, has been that because the production boundary was left unchanged no additional production or consumption was incorporated in the system. Consequently, the accounting presentation and balancing could only be accomplished by equating the production and consumption of environmental services to the consumption of "environmental" capital - or degradation.

Second, given this interpretation, the current ecosystem accounting model which extends the production boundary gives far greater freedom in recognizing the distinction between assets and services. Hence while there is a relationship between the value of ecosystem services and the value of degradation there does not need to be an equality between these two variables. Vanoli himself opens 
the door to this expanded production boundary approach towards the end of his 1995 paper. The following quotation makes for interesting reading some 20 years on

"if we were able to estimate the ecological value of forests and the services provided by them in a way permitting aggregation at the total economy level, we would have to introduce a new type of asset, such as "eco-systems of cultivated forests", a new output of services (ecological services) and an increased income and final consumption.” (Vanoli 1995, p131)

There is clearly attraction in the measurement of restoration costs. Indeed there are some very useful applications of this information, for example in the preparation of budgets and the assessment of the effectiveness of environmental protection expenditure. However, they should not be used as a proxy for accounting measures of degradation, given the ecosystem accounting developments of recent years.

\section{Challenges in integrating valuations in an accounting context}

The work on ecosystem accounting provides a comprehensive framework for the consideration of the valuation of ecosystem services in an accounting context. Further, the relationships and principles that underpin an accounting system have a range of important implications that are relevant when considering how values of ecosystem services and ecosystem assets might be integrated with standard national accounting information, such as GDP and national wealth.

At the same time there are some particular conceptual and practical challenges that remain to be resolved in order for a full integration of ecosystem services values within a national accounting context. This section notes some of these challenges, recognizing that the ongoing development of valuation methods for ecosystem services will, over time, enhance the possibilities for including ecosystem service and ecosystem asset values in accounting frameworks. 
In the valuation of provisioning services a conceptually appropriate approach is the application of resource rent or production function based approaches (UN et al. 2013, p125). These approaches start from an observed market price for a good (e.g. landed fish) and deduct relevant production costs (labour, produced assets, intermediate inputs) to estimate a residual that reflects the price of the ecosystem service. While conceptually sound, a practical outcome in the application of this approach can be that the residual, i.e. the resource rent, is low or negative, thus implying that the ecosystem service has a low or zero price.

A common and widespread example of this issue concerns water resources. In many countries attempts to value water resources using standard resource rent approaches have proved unsuccessful as many water supply companies operate while using prices that only cover operating costs (including produced assets) and sometimes not even that. The existence of zero or negative resource rents in this case then lead to the conclusion that water does not have a value in its own right and the ecosystem contribution to water supply is zero. Examples of this outcome include Australia (Comisari and Vardon, 2013) and the Netherlands (Edens and Graveland, 2014).

More generally with respect to natural resources, a common assumption in pricing ecosystem services is to assume that the use of the resource is sustainable, i.e. there are no depletion or degradation costs (see Bateman et al. 2011). However, even if the resource extraction is sustainable, existing market structures may drive unit resource rents to zero (see for example the case of open access to fish resources noted by Mäler 2009). The general conclusion is that the derivation of low or negative resource rents is likely to reflect the existing market structures, including subsidies, surrounding the extraction of the natural resources.

Following the logic for exchange values as defined in Section 2, this outcome of zero values for some natural resources would seem to be something that national accountants must accept. However, the extension of the production boundary through the ecosystem accounting framework has recognized the generation of ecosystem services as a productive activity. The extension of the production boundary implies that a transaction should be imputed between a supplier (which in the case of ecosystem 
accounting is considered the ecosystem asset) and a user. Further, this imputed transaction should be valued at an exchange value greater than zero.

We therefore conclude that resource rent type approaches are inappropriate in cases where market structures do not permit the observed market price to incorporate a reasonable exchange value for the relevant ecosystem service. Under these circumstances, alternative approaches, for example, replacement cost approaches, may need to be considered (Edens and Graveland 2014).

\section{Derivation of values for ecosystem assets}

In ecosystem accounting, the starting point for valuing ecosystem assets is to estimate the aggregated net present values of the future flows of each ecosystem service from an ecosystem asset. The valuation is therefore constrained by the production boundary that determines the scope of the ecosystem services to be included. In this regard the national accounting approach differs from wealth accounting approaches where a much wider range of aspects of wealth (e.g. time and health) is sometimes included (UNU-IHDP (2014). The connection between the production boundary and the valuation of assets is important for national accounting since it permits the alignment of measures of production, income, assets and degradation.

This approach to valuation is essentially consistent with approaches in accounting for individual resources, for example for fish, timber, mineral and energy resources, where the general approach is to estimate the stock of the resource, assess past patterns of extraction/harvest and estimate an asset life, often assuming that the extraction pattern is relatively constant into the future. This approach provides valuations that can be integrated with the values of other assets after taking account of likely overlaps in valuation. For example, current market prices for land are likely to include the value of some aspects of ecosystem assets and hence in an aggregate balance sheet a simple addition of land and ecosystem assets would be inappropriate.

However, in the case of ecosystems, where extraction rates of provisioning services in many ecosystems exceed the regenerative capacity of the ecosystem, it is also important to understand the capacity of the ecosystem to generate specific ecosystem services into the future recognizing that ecosystem should be considered potentially sustainable (Schröter et al., 2014). 
Two particular challenges arise. The first concerns determining the future flows of ecosystem services, or more specifically, the expected actual flows of a basket of ecosystem services, which will depend on the expected management and pattern of use of the ecosystem. Moreover, the nature of expected flows will be determined by the condition of the asset. However, the relationship between the asset condition and the capacity of the ecosystem to generate specific services may be dynamic and non-linear (e.g. Scheffer et al. 2002, Walker et al. 2009). In spite of the complexities, such exercises have been undertaken for some ecosystem types, for example forests (Schröter et al., 2014), where expected flows of a number of ecosystem services, including timber production, were evaluated in conjunction. Broadening the coverage of these exercises and incorporating them into an ecosystem accounting framework is an important part of the path forward.

The second challenge concerns the measurement of degradation. In a standard accounting situation and ignoring unexpected changes in assets, degradation would be valued based on the change in the NPV just described. However, an alternative approach is to consider that degradation should be measured as the change in the sustainable capacity of an ecosystem asset as measured between two points in time. This capacity can be envisioned as the aggregate of the value of the sustainable yields for each relevant ecosystem service. If the overall ecosystem condition falls, then the corresponding value of capacity is also likely to fall, thus providing an estimate of degradation.

In the limiting case where expected actual flows equal the sustainable yields for all ecosystem services these estimates of degradation will align. However, this is not commonly the case. Further research is needed to understand the accounting implications of valuing sustainable capacity since this issue does not arise in cases where assets have relatively defined lives and the application of NPV is quite straightforward.

\section{Accounting for ecosystem disservices}

The ecosystem accounting model and measurement of ecosystem services generally implicitly assume that ecosystem services have a positive effect on well-being. Human experience however recognizes that our relationship with nature is not always positive and this has led to the notion of ecosystem disservices, such as pests or carbon emissions from degrading ecosystems. 
Unfortunately, accounting principles do not work well when trying to make a distinction between products that may be considered as either "goods" and "bads". Accounting makes no assumptions as to the welfare effects of use and focuses instead on the activity associated with the generation of products and the associated patterns of use by economic actors. As a consequence all flows between producers and consumers have positive values in the accounts irrespective of their possible welfare effects. The positive values arise since it is difficult to envisage either component of value, prices or quantities, being negative.

Since ecosystem disservices are defined based on flows that negatively affect welfare, the challenge from an accounting perspective is thus how to incorporate a flow that must have a positive value (for accounting purposes) but also would seem to reduce measured levels of consumption. For instance, drained peat lands may generate important disservices by emitting significant quantities of carbon dioxide (Sumarga and Hein, 2014).

The issue of ecosystem disservices is directly related to the measurement of negative externalities. As noted in Section 2, the standard national accounting system does not incorporate externalities. This may mean that accounting must simply ignore these aspects of our relationship with the environment. However, this would limit our understanding of the relationship between changes in ecosystem assets and production and would also lead to difficulties in the aggregation of ecosystem service values within ecosystem assets. For instance, it may well be that some parts of an asset generate a disservice (e.g. carbon dioxide emissions) whereas other parts generate a positive service (e.g. carbon sequestration). Accounting for only the flows of positive services would imply quite a different interpretation compared to accounting for a net effect within the ecosystem asset (see for example, Sumarga and Hein, 2014).

We note two considerations that may help advance discussion of this challenge. First, it is noted that negative externalities often arise from the degradation or depletion of an ecosystem. Thus, at least in these instances, accounting for externalities and some disservices may be better tackled from the perspective of measuring the changes in the condition of ecosystem assets rather than via ecosystem services. At the same time, in accounting terms, the value of degradation will only be a partial measure for the externality that would normally incorporate changes in consumer surplus. 
Second, the assessment of disservices is likely to require an understanding of dependencies between ecosystems since the experience of ecosystem disservices in one area may well reflect imbalances in ecosystem functioning in other areas as in the case of some pests generated in natural ecosystems bordering croplands.

Overall, the approach of deducting bads from goods is not easily reflected within an accounting approach and more work is needed to develop relevant accounting treatments. Indeed this finding highlights the challenge faced when following the approach of Kuznets (1954) to the adjustment of GDP as noted in the introduction to this paper.

Full integration with the standard national accounts

The final challenge noted here concerns the steps that are required to fully integrate values of ecosystem services and ecosystem assets within the standard suite of national accounts, including production, income, and capital accounts and balance sheets. There are two areas that require resolution. The first area is the appropriate way to record and allocate measures of ecosystem degradation across institutional sectors (i.e. corporations, government, households). The SEEA EEA (see also Edens and Hein 2013) outlines two approaches which each may be appropriate depending on assumptions made about the ownership and attribution of ecosystem assets and their degradation.

The first approach considers the ecosystem as a new "quasi" institutional sector that transacts ecosystem services with the standard institutional sectors. In this approach degradation is attributed to the ecosystem and hence is not recorded as a deduction from income of economic units. In a second approach the ecosystem asset is attributed to "owning" sectors and degradation is attributed to those sectors. Here, the partitioning of the asset may well be problematic. For example, if a forest is considered to generate both timber provisioning and air filtration services then, ideally under this approach, the value of the ecosystem associated with the timber services should be attributed to the forestry industry while the air filtration services would be attributed to, perhaps, the government sector on behalf of households.

The second area concerns the integration of ecosystem asset values with the value of assets that are already included on national balance sheets. For example, a national balance sheet may include the 
value of timber resources following standard SNA and SEEA Central Framework approaches. Since the valuation of a forest ecosystem will include the value of timber, then to avoid double counting in the measurement of total wealth, it is necessary to adjust the total value of the ecosystem asset (derived by aggregating the net present value of all relevant ecosystem services) or exclude the separate value of the timber resources.

This issue is likely to be particularly problematic with respect to land where it is quite likely that the land value based on market, exchange values, will include implicitly a range of provisioning services, regulating services and potentially cultural services. The task of determining the extent of the potential overlap is a distinct challenge particularly in seeing how market land values may be connected to the values of individual ecosystem services.

Notwithstanding the existence of technical challenges, there are broader concerns about whether the valuation of non-market ecosystem goods and services is an exercise of merit. Concerns exist about the potential usefulness of "commoditizing" nature in terms of informing policy decisions (Soma, 2006; Kosoy and Corbera, 2010) and also, from a purely economic perspective, about whether the aggregate, national level valuations of ecosystem assets and services can be derived consistently with the underlying assumptions that are relevant for observed market prices (Radermacher and Steurer, 2014). Thus, in addition to meeting the challenges discussed in this section, more effort is also needed to clarify both the way valuation can support reaching a better understanding of ecosystem change and informing policies, and the limitations of the various valuation approaches.

\section{Conclusion}

The development of the school of thinking and research on ecosystem services has created considerable potential for extending national accounting beyond its standard production boundary and hence revealing more clearly the ways in which ecosystem services, assets and degradation may be taken into account in assessing standard measures of production, income and wealth. 
In return, the consideration of ecosystem services in an accounting context identifies a number of areas in which the approaches to valuation of ecosystem services and the description of the relationship between ecosystem services and ecosystem assets need to be better articulated. These areas include defining the appropriate valuation concept, distinguishing clearly between ecosystem services and benefits, distinguishing between ecosystem services and ecosystem degradation, and understanding the relationship between restoration costs and the measurement of ecosystem degradation.

The development of ecosystem accounting is however not yet complete. There remain a number of important conceptual and measurement challenges to resolve. The key challenges include accounting for low and negative resource rents, deriving values for ecosystem assets, accounting for regulating services that provide inputs across multiple spatial areas, accounting for ecosystem disservices and achieving a full integration of ecosystem accounting within the standard national accounts.

The authors consider that progress requires a strong understanding of the links between the various traditions that have developed in the economic, ecological and accounting disciplines. Thus, we are strongly of the view that these challenges will be better dealt with if economists, ecologists and accountants can work together to integrate the distinct perspectives that each apply. It is hoped that this paper is a contribution to building a common understanding. 


\section{Notes}

[1] Interestingly though, at the time, these debates on welfare were not overly concerned with the state of the environment. For instance, Nordhaus and Tobin (1972) state: "If we had estimates of the value of environmental capital, we could add them to the national wealth estimates ... and modify our calculations of MEW [measure of economic welfare] net investment accordingly. We have not been able to make this, adjustment, but given the size of the other components of wealth, we do not believe it would be significant."

[2] For a catalogue of examples of environmental-economic accounting see the on-line library held by the United Nations Statistics Division at http://unstats.un.org/unsd/envaccounting/ceea/archive/

[3] While this concept is clear, its application in the case of the use of environmental assets is challenging. See the discussion on the distinction between natural and cultivated resources in SEEA Central Framework 5.24-5.29

[4] Nordhaus (2005) describes these as near market goods and services. He notes that "Near market goods and services obey the "third party rule" which states that a third party could produce the good or service just as well as the party that produces the item.” (Nordhaus 2005, p5)

[5] Unlike the SEEA 2012 Central Framework which was recognized as a statistical standard by the United Nations Statistical Commission, SEEA Experimental Ecosystem Accounting does not represent a standard for measurement. Nonetheless it is hoped that it can provide an integrated framework and baseline for discussion on ecosystem accounting research, and facilitate the transition of this research into broader economic accounting systems and related decision making tools.

[6] There are many challenges in defining a set of mutually exclusive areas. For discussion see SEEA EEA section 2.3.

[7] Similar terms are used for the same model in other cases. For example, the UK NEA and Bateman et. al. (2011) use ecosystem services in the same way but apply the term "goods" rather than "benefits". Other approaches may skip the step of benefits (as defined here) and rather consider a direct link between ecosystem services and human well-being. The "extra" step is considered important for national accounting purposes such that integration with (and extension beyond) standard economic measures can be more easily facilitated. 


\section{References}

Ahmad Y J, El Serafy S, Lutz E (eds) (1989) Environmental accounting for sustainable development. World Bank, Washington D.C.

Alfsen K H, Bye T, Lorentsen L (1987) Natural Resource Accounting and Analysis. The Norwegian experience 1978-1986. Social and Economic Studies No. 65. Statistics Norway, Oslo

Arrow K, Dasgupta P, Mäler K-G (2003) Evaluating Projects and Assessing Sustainable Development in Imperfect Economies. Environmental and Resource Economics 26(4):647-85

Arrow K, Dasgupta P, Goulder L H, Mumford K J, Oleson K (2012) Sustainability and the Measurement of Wealth. Environment and Development Economics 17(3).

Ayres R U, Kneese A V (1969) Production, Consumption, and Externalities. American Economic Review 69:282-97.

Banzhaf S, Boyd J (2012) The architecture and measurement of an ecosystem services index. Sustainability 4:430-461

Barbier E (2013) Wealth accounting, ecological capital and ecosystem services. Environment and Development Economics 18(2):133-161

Barbier E (2014) "Challenges to ecosystem service valuation for wealth accounting." Chapter 7 in UNU-IHDP and UNEP. Inclusive Wealth Report 2014. Measuring Progress Toward Sustainability. Cambridge University Press, Cambridge, UK, pp. 159-177

Bateman I J, Mace G M, Fezzi C, Atkinson G, Turner K (2011) Economic analysis for ecosystem service assessment. Environmental and Resource Economics 48: 177-218.

Bateman I J, Harwood A R, Mace G M, Watson R T, et. al. (2013) Bringing Ecosystem Services into Economic Decision-Making: Land Use in the United Kingdom. Science 341:45-50, July 8

Brander L M, Florax R J G, Vermaat J E (2005) The empirics of wetland valuation: a comprehensive summary and a meta-analysis of the literature. Environmental and Resource Economics 33:223-250.

Brauman K A, Daily G C, Duarte T K E \& Mooney H A (2007) The Nature and Value of Ecosystem Services: An Overview Highlighting Hydrologic Services. Annual Review of Environment and Resources, 32(1), 67-98.

Brouwer R, Barton D, Bateman I, Brander L, Georgiou S, Martín-Ortega J, Navrud S, PulidoVelazquez M, Schaafsma M, Wagtendonk A (2009) Economic Valuation of Environmental and Resource Costs and Benefits of Water Uses and Services in the Water Framework Directive: Technical Guidelines for Practitioners.

Campos P, Caparrós A (2011) RECAMAN PROJECT Mediterranean Monte Ecosystems total income green accounting. Presentation to the Expert Meetingon Ecosystem Accounting, May 2011, European Environment Agency, Copenhagen, Denmark. 
Cobb C, Halstead T, Rowe J (1995) If the GDP is up, why is America down?, The Atlantic Monthly, 276, 59-78

Comisari P, Vardon M (2013) Valuation and treatment of water resource stocks. Paper presented to the $19^{\text {th }}$ meeting of the London Group of Experts on Environmental Accounting, London, 12-14 November 2013

Commission interministérielle des comptes du patrimoine naturel, Ministère de l'environnement (19811983), Institut national de la statistique et des études économiques (INSEE) (1986) Les Comptes du Patrimoine Naturel. Collections de l'INSEE. Série C, comptes et planification, 137-138. INSEE, Paris

Convention on Biological Diversity (2010) Strategic Plan for Biodiversity 2011-2020, http://www.cbd.int/sp/targets/

Costanza, R, d'Arge R, de Groot R, Farber S, Grasso M, Hannon B, Limburg K, Naeem S, O’Neill R V, Pareulo J, Raskin R G, Sutton P C, van den Belt M (1997) The value of the world's ecosystem services and natural capital, Nature, 387, 253-260

Costanza, R, de Groot R, Sutton P C, van der Ploeg S, Anderson S, Kubiszewski I, Farber S, Turner R K (2014) "Changes in the global value of ecosystem services." Global Environmental Change(26): $152-158$.

Dasgupta P S (2009) The Welfare Economic Theory of Green National Accounts. Environmental \& Resource Economics 42(1):3-38

Dasgupta, P S, Heal G M (1974) The Optimal Depletion of Exhaustible Resources. Review of Economic Studies, Symposium on the Economics of Exhaustible Resources

Daly H, Cobb J (1989), For the Common Good, Beacon Press, Boston

Edens B, Hein L (2013) Towards a consistent approach for ecosystem accounting. Ecological Economics 90:41-52

Edens B, Graveland C (2014) Experimental valuation of Dutch water resources according to SNA and SEEA doi:10.1016/j.wre.2014.10.003

European Commission (2011) The EU Biodiversity Strategy to 2020, Publications office of the European Union, Luxembourg

European Commission, International Monetary Fund, Organisation for Economic Co-operation and Development, United Nations, World Bank (2009) System of National Accounts 2008. United Nations, New York

Folke C, Carpenter S, Walker B, Scheffer M, Elmqvist T, Gunderson L, Holling C S (2004) Regime Shifts, Resilience, and Biodiversity in Ecosystem Management. Annual Review of Ecology, Evolution, and Systematics 35:557-581

Haines-Young R, Potschin M (2013) Common International Classification of Ecosystem Services (CICES), Consultation on version 4, August-December 2012. EEA Framework Contract No EEA/IEA/09/003 
Harrison A (1993) The Draft Handbook and the UNSTAT Framework: Comments. In: Lutz E (ed) Toward Improved Accounting for the Environment. World Bank, Washington D.C.

Hartwick J M (1977) Intergenerational Equity and the Investing of Rents from Exhaustible Resources. American Economic Review 66:972-974.

Heal G, Kriström B (2005) Chapter 22 National Income and the Environment. Handbook of Environmental Economics 3:1147-1217

Hicks J R (1946) Value and Capital: An Inquiry into Some Fundamental Principles of Economic Theory. Oxford, Clarendon Press, 1946

Hicks J R (1975) The scope and status of welfare economics, Oxford Economic Papers, no 3, 307-326

Hill R J, Hill T P (2003) Expectations, capital gains and income. Economic Enquiry 41(4), 607-619.

Hooper D U, Chapin F S III, Ewel J J, Hector A, Inchausti P, Lavorel S, Lawton J H, Lodge D M, Loreau M, Naeem S, Schmid B, Setälä H, Symstad A J, Vandermeer J, Wardle D A (2005) Effects of biodiversity on ecosystem functioning: a consensus of current knowledge. Ecological Monographs $75: 3-35$

Hueting R (1980) New scarcity and economic growth. North-Holland Publishing Company, Amsterdam

Kosoy N, Corbera E (2010) Payments for ecosystem services as commodity fetishism, Ecological Economics, 69(1), 1228-1236

Kuznets S (1954) Economic Change, 192-215

Mäler K-G, Aniyar S, Jansson ̊̊ (2009) Accounting for ecosystems. Environmental and Resource Economics 42:39-51

Meadows D H, Meadows D L, Randers J, Behrens W W (1972) Limits to Growth. Reports for the Club of Rome. Potomac Associates Book, Washington D.C.

Millennium Ecosystem Assessment (2003) Ecosystems and human well-being: A framework for assessment. Island Press, Washington, D.C.

Millennium Ecosystem Assessment (2005) Volume I. Ecosystems and human well-being: Current state and trends. Island Press, Washington, D.C.

National Research Council (2005) Valuing Ecosystem Services: Toward Better Environmental Decision Making, Washington DC, National Academy Press

Nordhaus W D (2005) Principles of national accounting for non-market accounts. Revised January 5, 2005. Paper presented to the Conference on Research in Income and Wealth (CRIW): A New Architecture for the US National Accounts, 16-17 April 2004.

Nordhaus, W D, Tobin J (1972) Is growth obsolete? Columbia University Press, New York. 
Pezzey, J C V, Toman M A (2002) The economics of sustainability: a review of journal articles. Resources for the Future.

Peskin H M (1976) A national accounting framework for environmental assets. Journal of Environmental Economics and Management 2:255-262

Press Information Bureau, Government of India (2013) Executive Summary of 'Green National Accounts in India a Framework - Report of the Expert Group'. http://pib.nic.in/archieve/others/2013/apr/d2013040501.pdf

Radermacher W, Steurer A (2014) Do we need natural capital accounts, and if so, which ones?, Paper presented to the High Level Expert Group on the Measurement of Economic Performance and Social Progress, Rome, September 2014.

Remme, R P, Schröter M, Hein L (2014). Developing spatial biophysical accounting for multiple ecosystem services. Ecosystem Services 10, 6-18

Scheffer M, Carpenter S, Foley J A, Folke C, Walker B (2002) Catastrophic shifts in ecosystems, Nature 413, 591-596

Schröter M, Barton D N, Remme R P, Hein L (2014) Accounting for capacity and flow of ecosystem services: A conceptual model and a case study for Telemark, Norway. Ecological Indicators 36:539551

Solow R M (1974) Intergenerational Equity and Exhaustible Resources. Review of Economic Studies, Symposium on the Economics of Exhaustible Resources 41:29-46.

Soma K (2006) Natura economica in Environmental Valuation, Environmental Values 15, No. 1, 31-50

Sumarga E, Hein L (2013) Mapping ecosystem services for landscape planning, the case of Central Kalimantan. Environmental management in press.

TEEB (2010) The economics of ecosystems and biodiversity, Mainstreaming the economics of nature. A synthesis of the approach, conclusions and recommendations of TEEB. Routledge, Oxford, UK

UK National Ecosystem Assessment (2011) The UK National Ecosystem Assessment: Synthesis of the key findings. UNEP-WCMC, Cambridge

United Nations (1953) A System of National Accounts and Supporting Tables. Studies in methods, Series F, No 2. United Nations, New York

United Nations (1992) Agenda 21: Programme of action for sustainable development. United Nations Conference on Environment and Development, Rio de Janeiro, 3-14 June 1992, United Nations, New York

United Nations (1993) Handbook of National Accounting: Integrated Environmental and Economic Accounting, Interim version. Studies in methods, Series F, No. 61. United Nations, New York.

United Nations General Assembly (2012) The Future We Want, Resolution 66/288, 27 July, 2012 
United Nations (2014) Open Working Group proposal for Sustainable Development Goals. Document $\mathrm{A} / 68 / 970$.

United Nations, European Commission, International Monetary Fund, Organisation for Economic Cooperation and Development, World Bank (1993) System of National Accounts 1993, United Nations, New York

United Nations, European Commission, International Monetary Fund, Organisation for Economic Cooperation and Development, World Bank (2003) Handbook of national accounting: Integrated environmental and economic accounting, 2003. Studies in methods, Series F, No 61. United Nations, New York

United Nations, European Commission, Organisation for Economic Co-operation and Development, The World Bank (2013) System of Environmental-Economic Accounting 2012 - Experimental Ecosystem Accounting. White cover publication, pre-edited text subject to official editing. United Nations, New York

United Nations, European Commission, Food and Agricultural Organization of the United Nations, International Monetary Fund, Organisation for Economic Co-operation and Development, The World

Bank (2014) System of Environmental-Economic Accounting 2012 - Central Framework. United Nations, New York

UNU-IHDP and UNEP (2014) Inclusive Wealth Report 2014. Measuring Progress Toward Sustainability. Cambridge University Press, Cambridge, UK

Vanoli A (1995) Reflections on Environmental Accounting Issues. Review of Income and Wealth 41(2):113-137

Vanoli, A (2005) A history of national accounting. IOS Press, Amsterdam

Walker B, Pearson L, Harris M, Mäler K-G, Li C-Z, Biggs R, Baynes T (2010) Incorporating resilience in the assessment of inclusive wealth: An example from south-east Australia. Environmental and Resource Economics 45(2):183-202

Weber J-L (2012) Recording Ecological Debts in the National Accounts: Possibilities open by the development of ecosystem capital accounts. Paper submitted to the ISEE2012 Conference, Rio de Janeiro.

Weitzman, M L (1976) On the welfare significance of National Product in a Dynamic Economy. Quarterly Journal of Economics, Vol. 90(1), 156-162.

World Bank (2011) The Changing Wealth of Nations. World Bank, Washington D.C.

World Commission on the Environment and Development (1987) Our Common Future. Oxford University Press, Oxford 


\section{University Library}

\section{- M M N E R VA A gateway to Melbourne's research publications}

Minerva Access is the Institutional Repository of The University of Melbourne

Author/s:

Obst, C;Hein, L;Edens, B

Title:

National Accounting and the Valuation of Ecosystem Assets and Their Services

Date:

2016-05-01

Citation:

Obst, C., Hein, L. \& Edens, B. (2016). National Accounting and the Valuation of Ecosystem Assets and Their Services. ENVIRONMENTAL \& RESOURCE ECONOMICS, 64 (1), pp.1-23. https://doi.org/10.1007/s10640-015-9921-1.

Persistent Link:

http://hdl.handle.net/11343/282878 